\title{
Effect of feeding genetically modified Bt-corn on allergic disease
}

\author{
Daniela Reiner", Rui-Yun Lee, Michelle M Epstein \\ From Food Allergy and Anaphylaxis Meeting 2011 \\ Venice, Italy. 17-19 February 2011
}

The rising prevalence of allergic disease in the last decades is unexplained. However, it has been postulated that the widespread introduction of genetically modified (GM) foods since 1996 may play a role in this evolving allergic disease epidemic. Currently, the most common GM plant is the genetically engineered Bacillus thuringiensis $(\mathrm{Bt})$-corn. This transgene confers resistance against corn borers leading to an enormous economic benefit. Corn products are found in a diverse variety of foodstuffs. Our hypothesis is that Bt-corn consumption influences allergic disease. We sought to determine whether feeding Bt-corn to mice would influence allergen-induced disease to a non-crossreactive allergen. To examine the influence of GM corn feeding on, the initiation and exacerbation of ovalbumin (OVA)-induced allergic asthma, we injected female BALB/c mice on days 0 and 21 with OVA intraperitoneally and nebulized them with OVA on days 28 and 29 to initiate disease and then allowed mice to recover until they were reexposed to OVA for the induction of a disease exacerbation. We fed mice pellets containing 33\% Bt (MON810)or isogenic-corn vs. normal mouse food containing no corn for 4 weeks prior to inducing disease or inducing disease exacerbation. To evaluate the effects of the Btcorn on OVA-induced disease, we measured lung and airway inflammation, mucus hypersecretion and OVAspecific antibodies. We observed that Bt-corn feeding had no effect on OVA-induced allergic disease or exacerbations indicating that Bt-corn using this protocol has no effect on the propensity for another allergen to initiate allergic disease or induce disease exacerbations in mice.

Medical University of Vienna, Vienna, Austria
Published: 12 August 2011

doi:10.1186/2045-7022-1-S1-P13

Cite this article as: Reiner et al:: Effect of feeding genetically modified Bt-corn on allergic disease. Clinical and Translational Allergy 2011 1(Suppl 1):P13.
Submit your next manuscript to BioMed Central and take full advantage of:

- Convenient online submission

- Thorough peer review

- No space constraints or color figure charges

- Immediate publication on acceptance

- Inclusion in PubMed, CAS, Scopus and Google Scholar

- Research which is freely available for redistribution
() Biomed Central
(C) 2011 Reiner et al; licensee BioMed Central Ltd. This is an open access article distributed under the terms of the Creative Commons Attribution License (http://creativecommons.org/licenses/by/2.0), which permits unrestricted use, distribution, and reproduction in any medium, provided the original work is properly cited. 